\title{
1.8 cineole decreases gastric compliance in anesthetized rats $^{1}$
}

\author{
1.8 cineol diminui a complacência gástrica de ratos anestesiados
}

\author{
José Ricardo Cunha Neves ${ }^{2}$, Gislano Heverton Soares de Lira ${ }^{3}$, Rocino Marinho de Oliveira Neto ${ }^{3}$, José Ronaldo \\ Vasconcelos da Graça ${ }^{4}$, Paulo Roberto Leitão de Vasconcelos ${ }^{5}$, Miguel Ângelo Nobre e Souza ${ }^{6}$, Pedro Jorge Caldas \\ Magalhães $^{7}$, Francisco Hélio Rola ${ }^{8}$, Armênio Aguiar dos Santos $^{7}$
}

1. Research performed at Laboratory School Prof. Luiz Capelo, Department of Physiology and Pharmacology of the College of Medicine, Federal University of Ceará (UFC). Brazil.

2. Fellow, Master degree in Surgery and Professor of Surgical Clinic, UFC. Sobral, Brazil.

3. Graduate Student, UFC. Brazil.

4. PhD, Associate Professor of Physiology,UFC. Sobral, Brazil.

5. PhD, Associate Professor, Coordenator Post-Graduation Program in Surgery, UFC. Brazil.

6. PhD, Volunteer Faculty, Department of Medical Clinic, UFC. Brazil.

7. PhD, Associate Professor, Department of Physiology and Pharmacology, UFC. Brazil.

8. PhD, Professor Post-Graduation Program in Pharmacology, UFC. Brazil.

\begin{abstract}
Purpose: To study the effect of 1,8 cineoleee components of the essencial oil of Croton nepetaefolius - plant of North-East of Brasil, used in the popular medicine for riots of the gastrointestinal tract - on the motor behavior of the gut of Wistar rats. Methods: Used 16 male animals under jejun of $24 \mathrm{~h}$ weighing $300-350 \mathrm{~g}$. The effect of 1.8 cineoleee $(1 \mathrm{or} 3 \mathrm{mg} / \mathrm{Kg}) \mathrm{on}$ gastric compliance had been lead in anaesthetized rats. The variations of the gastric volume (GV), had been measured by plethysmography, while AP, HR and CVP had been monitored continuously by a digital system of data acquisition. Results: Observe reduction of the GV, which was significant on 30, 40, 50 and $60 \mathrm{~min}$ after treatment $(2.0 \pm 0.1 ; 1.9 \pm 0.1$; $1.8 \pm 0.1$ and $1.7 \pm 0.1 \mathrm{~mL}$, versus $2.1 \pm 0.2 \mathrm{~mL}$ ). The AP presented significant fall after the administration of 1.8 cineoleee, remaining thus during $60 \mathrm{~min}$ of monitorization $(87.9 \pm 7.7 ; 87.6 \pm 7.1 ; 87.9 \pm 6.4 ; 87.8 \pm 5.7 ; 86.0 \pm 5.5$ and $87.7 \pm 6.0 \mathrm{mmHg}$, respectively versus $94.4 \pm 6.2 \mathrm{mmHg})$, as well as the $\mathrm{HR}(366.3 \pm 13.4 ; 361.7 \pm 11.5 ; 357.3 \pm 10.4 ; 353.0 \pm 10.4 ; 348.3 \pm 11.1$ and $350.4 \pm 13.7 \mathrm{bpm}$, respectively versus $395.2 \pm 11.1 \mathrm{bpm})$. The CVP did not suffer significant variations after treatment. Conclusion: Observe the 1.8 cineoleee reduces the gastric compliance in anaesthetized rats besides presenting effect hipotensor and bradicardic; probably for direct action on the gastrointestinal and vascular smooth muscel and moduling the autonomic nervous system.
\end{abstract}

Key words: Croton. Gastrointestinal Motility. Stomach. Rats.

\section{RESUMO}

Objetivo: Estudar o efeito do 1.8 cineol, componente do Cróton nepetaefolius (planta do Nordeste) comumente usada na medicina popular para distúrbios do trato gastrintestinal (TGI), sobre o comportamento motor do TGI de ratos Wistar anestesiados. Métodos: Utilizamos 16 animais machos, pesando entre 300 a 350g. Os estudos de complacência gástrica foram conduzidos em animais sob jejum de $24 \mathrm{~h}$. As variações do volume gástrico (VG), foram medidas por pletismografia, enquanto a PA, FC e PVC foram monitoradas continuamente por um sistema digital de aquisição de dados. Resultados: Observamos diminuição do VG, o qual foi significativo aos 30, 40, 50 e 60min após o tratamento com 1.8 cineol quando comparado ao perído basal $(2,0 \pm 0,1 ; 1,9 \pm 0,1 ; 1,8 \pm 0,1$ e $1,7 \pm 0,1 \mathrm{~mL}, v s 2,1 \pm 0,2 \mathrm{~mL})$. A PAapresentou queda significativa após a administração de 1.8 cineol, mantendo-se assim durante os 60 min de monitoração $(87,9 \pm 7,7 ; 87,6 \pm 7,1 ; 87,9 \pm 6,4 ; 87,8 \pm 5,7$; $86,0 \pm 5,5$ e $87,7 \pm 6,0 \mathrm{mmHg}$, respectivamente $v s 94,4 \pm 6,2 ; \mathrm{mmHg})$, bem como a FC $(366,3 \pm 13,4 ; 361,7 \pm 11,5 ; 357,3 \pm 10,4 ; 353,0 \pm 10,4$;

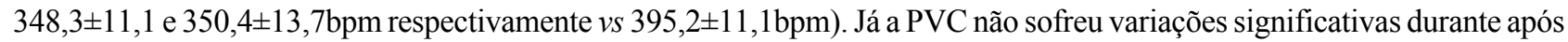
o tratamento. Conclusão: O 1.8 cineol diminui a complacência gástrica em ratos anestesiados além de apresentar efeitos hipotensor e bradicárdico; provavelmente por ação direta sobre a musculatura lisa gastrintestinal e vascular e modulação do sistema nervoso autônomo.

Descritores: Croton. Motilidade Gastrointestinal. Estômago. Ratos. 


\section{Introduction}

Croton nepetaefolius Baill is the scientific denomination of a type and common shrub in the Brazilian Northeast popularly known as marmeleiro sabiá, used in popular medicine folk for riots gastrintestinais ${ }^{1}$. Intragastric administration of the essential oil of the Croton nepetaefolius (EOCN) increases the time of gastrintestinal transit of a liquid meal in mice ${ }^{2}$. Already in vitro preparations of the intestinal smooth muscle of cobaio the EOCN demonstrated miorrelaxantes properties, diminishing tônus basal and reducing the amplitude of the spontaneous contractions of segments of íleo as well as of gastro-esophagicus, pyloric and ileocecal sphincter of cobaio ${ }^{3}$. These data demonstrate that the EOCN present mio-relaxant and antispasmodic properties in vivo and in vitro, consistent with the use in popular medicine folk ${ }^{1,4}$. We decide, then, to study the actions of the administration i.v of the 1,8 cineoleee, main component of the $\mathrm{EOCN}^{1}$, on the gastric compliance, arterial pressure, central venous pressure and cardiac frequency of anestesiados rats.

\section{Methods}

Male Wistar rats (300-350g, $\mathrm{n}=16)$ proceeding from the Central Breathing of the UFC was used. All procedures had been in accordance with the norms of the Brazilian College of Animal Experimentation (COBEA). The 1,8 cineoleee and EOCN was gentily granted by the Laboratory of the Prof. Jose Henrique Leal Cardoso University State of the Ceará.

\section{Surgical procedures}

We kept the animals in jejum for $24 \mathrm{~h}$ with free access to the water until $2 \mathrm{~h}$ hours before the experiments. After anesthesia with uretana $(1,2 \mathrm{~g} / \mathrm{kg}$, I.P.), we carry through traqueostomie, followed of the cannula insertion, in order to facilitate the spontaneous ventilation. Next, we insert polyethylene cannulas (PE 50), full of saline solution $0.9 \%$ with heparina $(500 \mathrm{U} / \mathrm{mL})$ in the left vein jugular and the right carotid artery. We destine the vein for administration of drugs or vehicle and monitoration of the central venous pressure while we use the artery for arterial pressure monitoration.

\section{Gastric volume measurements}

For the monitoration of the gastric volume (GV), we use the pletismometric model develop in ours laboratory ${ }^{5}$. Initially, we introduce per os, a polyethylene catheter $(\mathrm{ED}=2,0 \mathrm{~mm} / \mathrm{ID}=1,5 \mathrm{~mm})$ with a latex balloon (volume $4 \mathrm{~mL}$ ), which was posioned carefully in the proximal stomach. Next, we connect the free extremity of the catheter to liquid reservoir ( $\mathrm{ID}=2,5 \mathrm{~cm}$, maximum capacity of $30 \mathrm{~mL}$ ). The reservoir, the stomach and the balloon then, establish a comunicant system vassel, had been filled with conducting solution standard $[45 \mathrm{mg} \%$ of $\mathrm{NaCl}$ and $0.3 \mathrm{~mL} \%$ of polietilenoglicol (Imbebiente BBC Ornano $\left.\left.{ }^{\circledR}\right)\right]$ at $37^{\circ} \mathrm{C}$. Variations in gastric tonus capable to modify the liquid volume in a balloon, had been detected by an electronic volume sensor was continuously registered for one plethysmometer (Ugo Basile ${ }^{\circledR}$, Comerio, Italy). Given the constant pressure of the system, variations in gastric tonus, means variations on a gastric compliance ${ }^{5}$. In the beginning of each experiment, the stomach was submitted the distention for a pressure of $4 \mathrm{cmH}_{2} \mathrm{O}$, by rising the liquid level of the reservoir until $4 \mathrm{~cm}$ above of the xifoide appendix of the animal. Variations on gastric compliance had been monitored continuously, written down to each $30 \mathrm{~s}$, express in $\mathrm{mL}$.

\section{Monitoration of the cardiovascular parameters}

Mean arterial pressure (AP), central venous pressure (CVP) and cardiac frequency (CF) had been gotten by the connection of the arterial and venous cannules, respectively, the pressure transducers that had been connected to a acquisition system of data (PowerLabADInstrumesnts $\left.{ }^{\circledR}\right)$.

\section{Experimental protocols}

After surgical procedures, animals had been kept in rest for 30min for the stabilization of the hemodinamics parameters. All the animals had been studied by a period at least $80 \mathrm{~min}$, twenty min initial was considered as Basal period, after that 1.8 cineoleee $(1$ or $3 \mathrm{mg} / \mathrm{kg}-\mathrm{n}=11$ ) or vehicle (saline $0.9 \%-\mathrm{n}=5$ ) i.v. administration was perormed. We evaluated GV, AP, CVP and FC by more $60 \mathrm{~min}$, which had been divided in equal intervals of 10min, called 10, 20, 30, 40, 50 and 60 .

\section{Experimental avaliation}

To the end of each experiment, all the animals had suffered, still in plain anaesthetic, medium laparotomie for inspection of the positioning of the balloon was performed, being to follow sacrificed for injection e.v. of solution of $\mathrm{KCl}$. Excluded the data of animals with anomalous localization of the balloon.

\section{Statics analise}

Individual values of GV, CF, CVP and AP of diverse experimental groups are express in the text in Mean \pm SD. Analysis of variance ("One way - ANOVA") followed of Dunnett's test was used to compare the differences between averages of diverse experimental periods, as well as between the studied groups. Differences with $\mathrm{p}<0,05$ had been as significant.

\section{Results}

Figure 1 shows the variations of gastric volume $(\mathrm{GV})$, arterial pressure (AP), central venous pressure (CVP) and cardiac frequency $(\mathrm{CF})$ after and before 1.8 cineole treatmensts $(1 \mathrm{mg} / \mathrm{Kg}$, i.v. $)$. We observe reduction $(\mathrm{p}<0.05)$ on the $\mathrm{GV}$, which was significant at 30, 40, 50 and 60min after 1.8 Cineoleee treatments when compared a basal 
value $(2.0 \pm 0.1 ; \quad 1.9 \pm 0.1 ; \quad 1.8 \pm 0.1$ and $1.7 \pm 0.1 \mathrm{~mL}$ respectivelly, vs $2.1 \pm 0.2 \mathrm{~mL})$. Mean arterial pressure $(87.9 \pm 7.7 ; 87.6 \pm 7.1 ; 87.9 \pm 6,4 ; 87.8 \pm 5,7 ; 86.0 \pm 5,5$ and $87.7 \pm 6,0 \mathrm{mmHg}$, respectively vs $94.4 \pm 6.2 \mathrm{mmHg}$ ) as well as the CF $(366.3 \pm 13.4 ; 361.7 \pm 11.5 ; 357.3 \pm 10.4$; $353.0 \pm 10.4 ; 348.3 \pm 11.1$ and $350.4 \pm 13.7 \mathrm{bpm}$ respectively, vs $395.2 \pm 11.1 \mathrm{bpm}$ ) had presented significant falls after 1.8 cineoleee treatments, remaining themselves thus during $60 \mathrm{~min}$ of monitoration. Already, CVP did not suffer significant variations after 1.8 cineoleee treatments $(0.1 \pm 0.7 ; \quad 0.6 \pm 0.7 ; \quad 0.1 \pm 0.7 ; \quad 0.5 \pm 0.7 ; \quad 0.6 \pm 0.8$ and $1.0 \pm 0.9 \mathrm{CmH}_{2} \mathrm{O}$ versus $1.2 \pm 1.1 \mathrm{CmH}_{2} \mathrm{O}$ ). Figure 2 shows the variations of $\mathrm{GV}, \mathrm{AP}, \mathrm{FC}$ and $\mathrm{CVP}$ after and before 1.8 cineole treatmensts $(3 \mathrm{mg} / \mathrm{Kg}$, i.v.). We observe reduction $(p<0.05)$ on the $\mathrm{GV}$, which was significant at $30,40,50$ and $60 \mathrm{~min}$ after 1.8 Cineoleee treatments when compared a basal value $(2.0 \pm 0.2 ; 2.0 \pm 0.1$ and $2.0 \pm 0.1 \mathrm{~mL}$ respectively, vs $2.3 \pm 0.1 \mathrm{~mL})$. Mean arterial pressure $(83.4 \pm 4.4 ; 78.5 \pm 5.0$; $75.2 \pm 4.7 ; 70.4 \pm 4.6 ; 68.0 \pm 4.0$ and $67.5 \pm 3,7 \mathrm{mmHg}$,

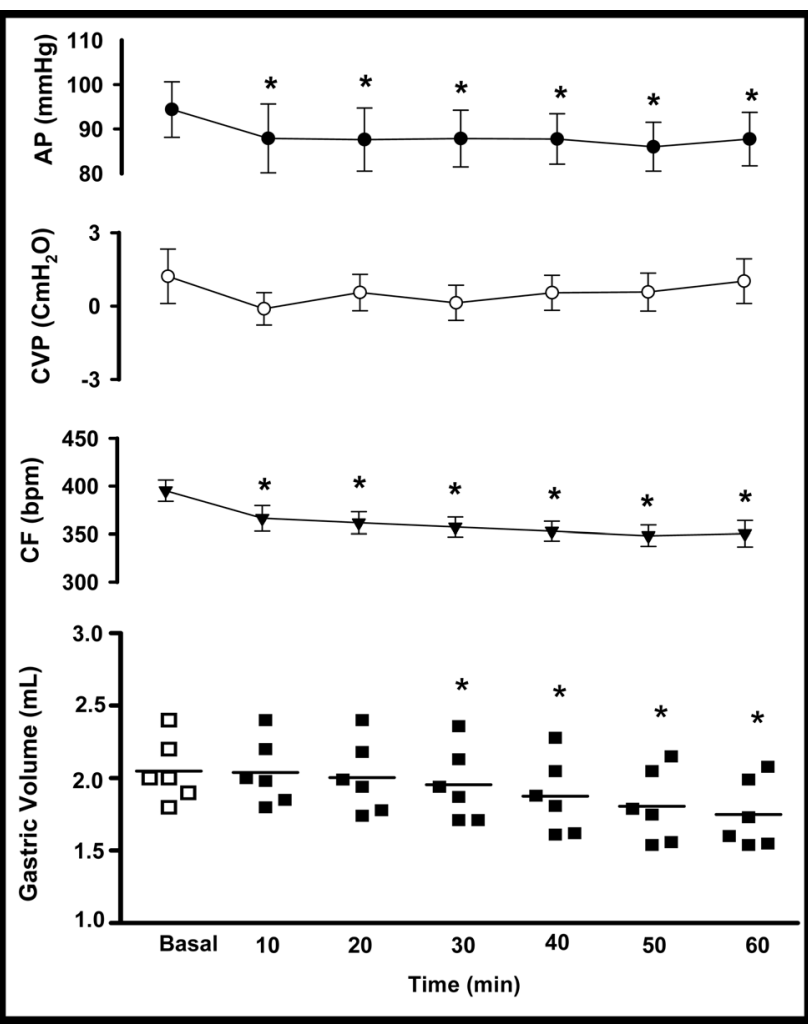

After a basal period of $20 \mathrm{~min}$, we treated the animals with 1.8 cineole $(1 \mu \mathrm{g} / \mathrm{Kg}, \mathrm{n}=6)$. The values of VG, AP, CVP and CF monitored during $60 \mathrm{~min}$ had been grouped in six consecutive intervals of $10 \mathrm{~min}$ $(10,20,30,40,50$ and 60 , respectively). The data of GV gotten by mean barostatic system are represented in a form of scatter with the horizontal line representing the median. The circles closed and opened and the closed triangles and the vertical lines represent mean \pm ED of the AP, CVP and CF, respectively. *, $\mathrm{P}<0,05$ versus basal period (ANOVA and Dunnett's test).

FIGURE 1 - Effects of 1.8 cineole on Arterial Pressure (AP, in $\mathrm{mmHg}$ ), Central Venous Pressure (CVP, in $\mathrm{CmH} 2 \mathrm{O})$, Cardiac Frequence (CF, in bpm) and gastric volume $(\mathrm{GV}$, in $\mathrm{mL})$ in an anesthetized rats. respectively vs $85.0 \pm 4.0 \mathrm{mmHg})$ as well as the CF $(353.5 \pm 13.2 ; 355.3 \pm 8.7 ; 352.3 \pm 7.1 ; 351.0 \pm 5.7 ; 346.3 \pm 7.3$ and $338.8 \pm 8.6 \mathrm{bpm}$, respectively $v s 382.3 \pm 11.4 \mathrm{bpm})$ had presented significant falls after 1.8 cineoleee treatments, remaining themselves thus during $60 \mathrm{~min}$ of monitoration. Already, CVP did not suffer significant variations after 1.8 cineoleee treatments $(2.2 \pm 0.1 ; 2.2 \pm 0.1 ; 2.1 \pm 0.1$; $2.0 \pm 0.1 ; 2.1 \pm 0.1$ and $2.1 \pm 0.1 \mathrm{CmH}_{2} \mathrm{O}$, respectively $v s$ $\left.2.2 \pm 0.1 \mathrm{CmH}_{2} \mathrm{O}\right)$. Figure 3 shows the variations of $\mathrm{GV}, \mathrm{AP}$, FC and CVP after and before placebo treatmensts $(0.2 \mathrm{~mL}$ of saline $0.9 \%$, i.v.). We do not observe significant variations on GV, AP, CVP or FC along $80 \mathrm{~min}$ of study $(2.2 \pm 0.2 ; 2.2 \pm 0.1 ; 2.2 \pm 0.2 ; 2.1 \pm 0.2 ; 2.1 \pm 0.2$ and $2.0 \pm 0.2 \mathrm{~mL}$ vs $2.2 \pm 0.2 \mathrm{~mL}),(92.2 \pm 3.9 ; 92.1 \pm 3.7 ; 91.0 \pm 3.5 ; 92.3 \pm 3.4$; $92.6 \pm 4.0 ; 92.3 \pm 4.1 \mathrm{mmHg}$ and $91.2 \pm 4.5 \mathrm{mmHg}),(0.1 \pm 1.1$; $0.8 \pm 1.2 ;-0.6 \pm 2.7 ; 0.6 \pm 2.4 ;-1.9 \pm 1.5 ;-2.8 \pm 1.9$ and $0.3 \pm 0.0 \mathrm{CmH}_{2} \mathrm{O}$ vs $\left.0.2 \pm 0.2 \mathrm{CmH}_{2} \mathrm{O}\right)$ and $(402.3 \pm 26.6$; $383.5 \pm 34.9 ; 374.5 \pm 32.5 ; 359.0 \pm 20.6 ; 353.3 \pm 26.0$; $347.0 \pm 27.1 \mathrm{bpm}$ and $366.7 \pm 27.2 \mathrm{bpm}$ ), respectively.

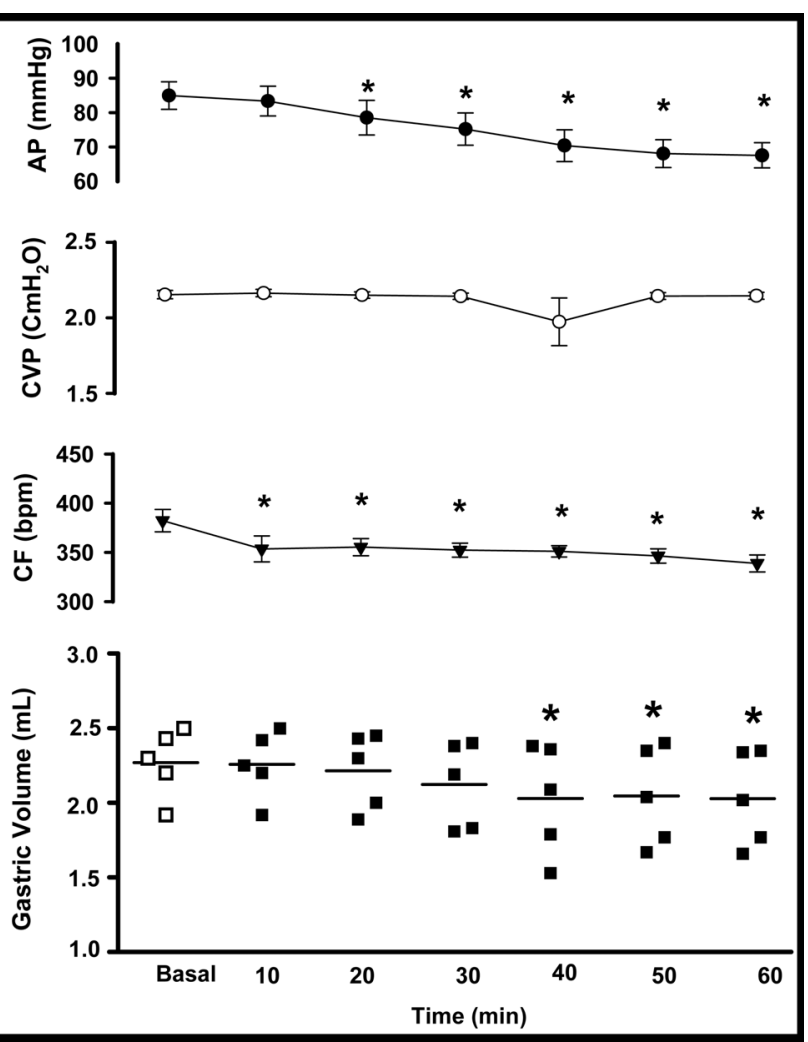

After a basal period of $20 \mathrm{~min}$, we treated the animals with 1.8 cineole $(3 \mu \mathrm{g} / \mathrm{Kg}, \mathrm{n}=5)$. The values of VG, AP, CVP and CF monitored during $60 \mathrm{~min}$ had been grouped in six consecutive intervals of $10 \mathrm{~min}$ $(10,20,30,40,50$ and 60 , respectively). The data of GV gotten by mean barostatic system are represented in a form of scatter with the horizontal line representing the median. The circles closed and opened and the closed triangles and the vertical lines represent mean $\pm \mathrm{ED}$ of the $\mathrm{AP}, \mathrm{CVP}$ and $\mathrm{CF}$, respectively. *, $\mathrm{P}<0,05$ versus basal period (ANOVA and Dunnett's test).

FIGURE 2 - Effects of 1.8 cineole on Arterial Pressure (AP, in $\mathrm{mmHg}$ ), Central Venous Pressure (CVP, in CmH2O), Cardiac Frequence ( $\mathrm{CF}$, in $\mathrm{bpm})$ and gastric volume $(\mathrm{GV}$, in $\mathrm{mL})$ in an anesthetized rats. 


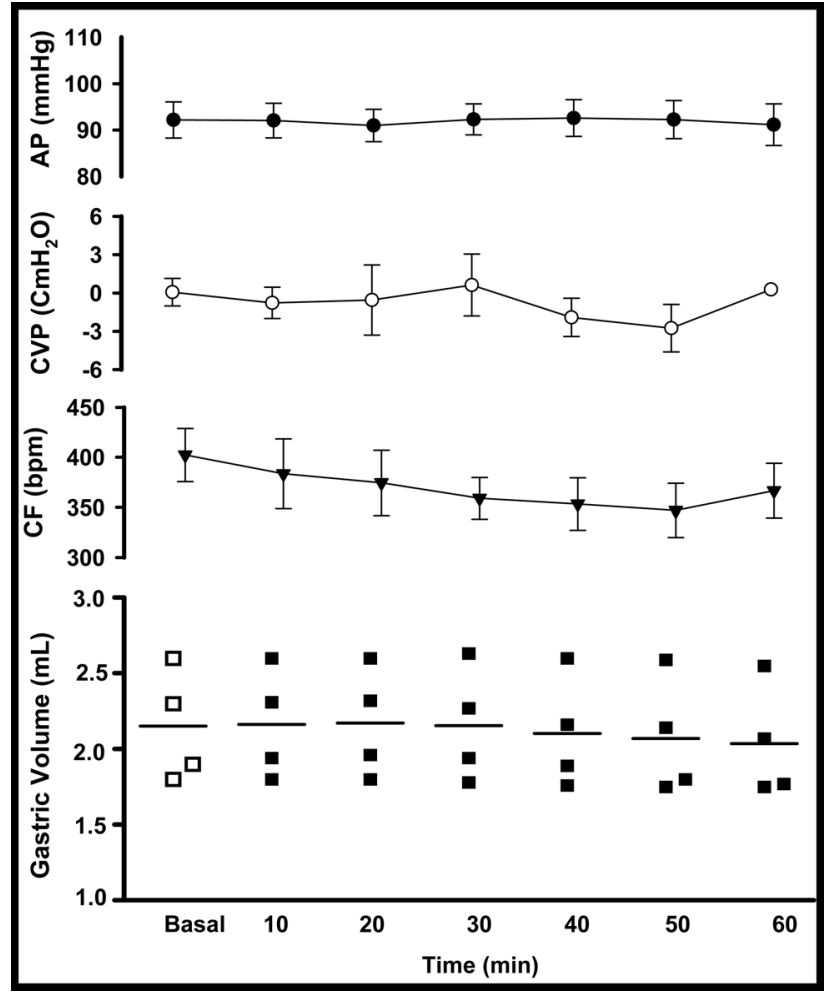

After a basal period of $20 \mathrm{~min}$, we treated the animals with saline $0,9 \%(0,2 \mathrm{~mL}$, i.v., $\mathrm{n}=4)$. The values of VG, AP, CVP and CF monitored during $60 \mathrm{~min}$ had been grouped in six consecutive intervals of $10 \mathrm{~min}(10,20,30,40,50$ and 60 , respectively). The data of $\mathrm{GV}$ gotten by mean barostatic system are represented in a form of scatter with the horizontal line representing the median. The circles closed and opened and the closed triangles and the vertical lines represent mean $\pm \mathrm{ED}$ of the $\mathrm{AP}, \mathrm{CVP}$ and $\mathrm{CF}$, respectively. *, $\mathrm{P}<0,05$ versus basal period (ANOVA and Dunnett's test).

FIGURE 3 - Effects of placebo (saline solution of 0,9\%) on Arterial Pressure (AP, in $\mathrm{mmHg}$ ), Central Venous Pressure (CVP, in $\mathrm{CmH} 2 \mathrm{O}$ ), Cardiac Frequence (CF, in bpm) and gastric volume $(\mathrm{GV}$, in $\mathrm{mL})$ in an anesthetized rats.

\section{Discussion}

This work shows that the 1.8 cineoleee i.v. administration reduces gastric compliance, arterial pressure, cardiac frequency of anestesiados rats, dose dependent, however does not modify central venosa pressure. Arterial pressure, CF and CVP had been monitored continuously. For this proposite, we use a data acquisition system (PowerLab-ADInstruments ${ }^{\circledR}$ ), considered standard for literature. Basal results of AP are similar to gotten for others ${ }^{6}$. 1,8 cineoleee presente an hipotensor effect, AP returned to basal levels to soon after $10 \mathrm{~min}$ of the treatment, similar to observed for others ${ }^{7,8,9}$. Data of literature show that i.v. administration of OECN or 1.8 cineole delays gastric emptying and gastrointestinal transit of liquid in awake rats as demonstrated by Magalhães et al., indicating that OECN and 1.8 cineole retard gastrintestinal transit in mice and relaxes the intestinal smooth musculatura of cobaio $^{2,3}$. According to a prevalent interpretation of specialists, delays of the gastric emptying of liquid, seamns a provoked by OECN and 1.8 cineole, folows a proximal stomach relaxation ${ }^{10}$ and/or an incresement of the antroduodenal resistance to a liquid flow, call "duodenal brake "11. Proximal and distal stomach, can determine different standards of GE for varied types and compositions of meals ${ }^{12}$. The proximal segment functions as reservoir, capable to accomodate the meal while the fasic contractions of the antrum and the body promotes the gradient pressure for mix intraluminal contents, propulsioning a gastric content for duodenum ${ }^{12,13}$. In the present study, to evaluate the effect of .8 cineole on the gut motilidade, we use a plethismometric system. A system previously developed and validated for Graça and colegues $^{5,14}$, it showns adequate to continuously monitoring gastric tonus variations of the proximal stomach. It reflects variations of gastric volume, at last, the gastric compliance. Beyond hipotensor and bradicardic effect, that 1.8 cineole is capable to increase, a dose dependent, the tonus of stomach, diminishing, therefore, the gastric compliance of anesthetized rats. These results, can is related to findings of Magalhães and co-workers ${ }^{2,3}$, which had described inhibitore effects of EOCN and 1.8 cineole on the gut muscels. The hipotensor and bradicardic effects of 1.8 cineole is hard. However these treatments do not modify the CVP of animals. In studies with waked up rats Lahlou and collaborators, that EOCN and 1.8 cineole, show bradicardic effect as well as hipotensor effect, probably for modulation of the nervous system autônomo ${ }^{7}$, by vagal action. The Croton nepetaefolius is sufficiently known for popular medicine application of riots of the gastrointestinal system ${ }^{16}$. We present effects of 1.8 cineole on the gastric compliance can result of an autonomic reflex, or direct action of this essential oil on smooth muscel. In studies in vitro 1.8 cineole presents miorelaxant effect, what probably it justifies the job of this plant for the popular medicine, however the mechanisms of action of this oil is not well clarify ${ }^{2}$. In the isolated intestine of cobaio the inibitório effect of the EOCN is not reverted by an inhibitor of the NO-sintetase (L-NAME), inhibitor of cicloxigenase (indometacin), ganglionar bloker (hexametonium), sodium canals bloker (tetrodotoxin) pre-treatments. In this model, essential oil does not involve NANC mediation ${ }^{2,3}$. Already the effect of the OECN on AP and CF of awaked rats involve the integrity of the autonomic parassimpatic inervation (vagus nerve), while the effect on sanguineous vases if give for direct action of the oil on the smooth muscel $\operatorname{vascular}^{7,8,9}$. That effect of 1.8 cineole on the gastric compliance also is related to increase on autonomic activity. Bilateral vagotomy blocks the effect of OECN and the 1.8 cineole on AP and $\mathrm{CF}^{8}$.

\section{Conclusion}

The 1.8 cineole, decreases the gastric compliance, arterial pressure, cardiac frequence in anestesiados rats. The inhibition of 1.8 cineole on the gut motilidade, may involves a systemic domain the modulation of the autonomic nervous system. 


\section{References}

1. Dantas TNC. Contribuição ao conhecimento químico de plantas do Nordeste: Croton aff nepetaefolius, Baill [Dissertação - Mestrado]. Universidade Federal do Ceará: Departamento de Química Orgânica; 1979.

2. Magalhaes PJ. Ações do óleo essencial do marmeleiro sabiá (Cróton nepetaefolius) na musculatura intestinal de cobaio [Dissertação - Mestrado]. Universidade Federal do Ceará: Faculdade de Medicina;1997.

3. Magalhães PJC, Criddle DN, Tavares RA, Melo EM, Mota TL, Leal-Cardoso JH. Intestinal myorelaxant effects of the essencial oil of Cróton nepetaefolius and ist constituents cineole, methyl-eugenol and terpinol. Phytother R. 1998;12:172-7.

4. Craveiro AA, Alencar JW, Matos FJA. Um sucedâneo vegetal para o óleo diesel: o marmeleiro. In: Seminário sobre energia para transportes. São Paulo; 1978. p.46-51.

5. Graça JRV, Leal PRL, Gondim FAA, Rola FH, Santos AA. A plethysmometric method for gastric compliance studies in anesthetized rats. J Pharmacol Toxicol Method. 2000;43:25-30.

6. Cardoso LM, Pedrosa ML, Silva ME, Moraes MF, Colombari E, Chianca DA Jr. Baroreflex function in conscious rats submitted to iron overload. Braz J Med Biol Res. 2005;38:205-14.

7. Lahlou S, Leal-Cardoso JH, Magalhaes PJ, Coelhode-Souza AN, Duarte GP. Cardiovascular effects of the essential oil of Croton nepetaefolius in rats: role of the autonomic nervous system. Planta Med. 1999;65:553-7.

8. Lahlou S, Leal-Cardoso JH, Magalhaes PJ. Essential oil of Croton nepetaefolius decreases blood pressure through an action upon vascular smooth muscle: studies in DOCA-salt hypertensive rats. Planta Med. 2000;66:138-43.
9. Lahlou S, Leal-Cardoso JH. Antispasmodic effects of the essential oil of Croton ileum: a myogenic activity nepetaefolius on guinea-pig. Fundam Clin Pharmacol. 2004;18:539-46.

10. Kelly KA. Gastric emptying of liquids and solids: roles of proximal and distal stomach. Am J Physiol. 1980;239:G71-6.

11. Weisbrodt NW. Gastrointestinal Motility. In: Leonard R. Johnson. 6ed. St. Louis, Missouri USA: Mosby; 2001.

12. Rao SSC and Schulze-Delrieu K. The stomach, pylorus and duodenum. Section 5: normal gastrointestinal motility. In: Kumar D, Wingate D. An illustrated guide to gastrointestinal motility. 2ed. New York: Churcill Livingstone; 1993.

13. Leal-Cardoso JH, Fonteles MC. Pharmacological effects of essential oils of plants of the northeast of Brazil. An Acad Bras Cienc. 1999;71:207-13.

14. Graça JRV, Leal PRL, Gondim FAA, Rola FH, Santos AA. Gastric compliance changes induced by acute blood volume variations in anaesthetised rats. Braz $\mathrm{J}$ Med Biol Res. 2002;35:405-10.

15. Capelo LR, Cavalcante DM, Leitão IA, Filho GC, daSilva EAT. Modifications of gastric compliance in dogs related to changes in extracellular fluid volume: a possible physiological role. Braz J Med Biol Res. 1983;16:73-6.

16. Craveiro AA, Fernandes AG, Andrade CHS. Óleos essenciais de plantas do Nordeste. Fortaleza: Edições UFC; 1981.

\section{Acknowledgments}

We thank to Prof. Dr. José Henrique Leal Cardoso for cession of the essential oil in its pure form.

\section{Correspondence:}

Prof. Ronaldo Graça

Faculdade Medicinade Sobral

Rua Geraldo Rangel, s/n

62040-180 - Sobral - CE - Brazil

Phone: (55 88)677-4241

e-mail: guaiuba@yahoo.com, guaiuba@sobral.org
Conflict of interest: none Financial sources: Unimed-Sobral, UFC and CNPq

Received: August 08, 2006

Review: September 12, 2006

Accepted: October 24, 2006

\section{How to cite this article:}

Neves JRC, Lira GHS, Oliveira Neto RM, Graça JRV, Vasconcelos PRL, Souza MAN, Magalhães PJC, Rola FH, Santos AA. 1.8 cineole decreases gastric compliance in anesthetized rats. Acta Cir Bras. [serial on the Internet] 2007 Jan-Feb;22(1). Available from URL: http://www.scielo.br/acb. 